\title{
בănọ Uิ
}

V11 المصاد 11 • العدد 2 • 2021 | 2021 |

IJSR is abstracted and indexed by: ABI/Inform (ProQuest), Cabell's Directory of Publishing Opportunities, Crossref, British Library and by most top universities across the world such as Oxford, Harvard, Cambridge, etc.

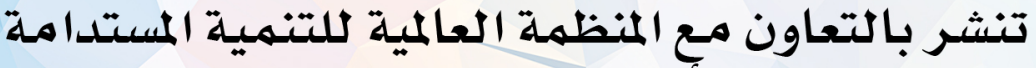

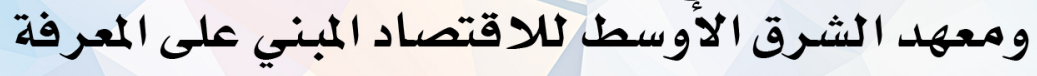
لندن، المملكة المتحدة التهرة.

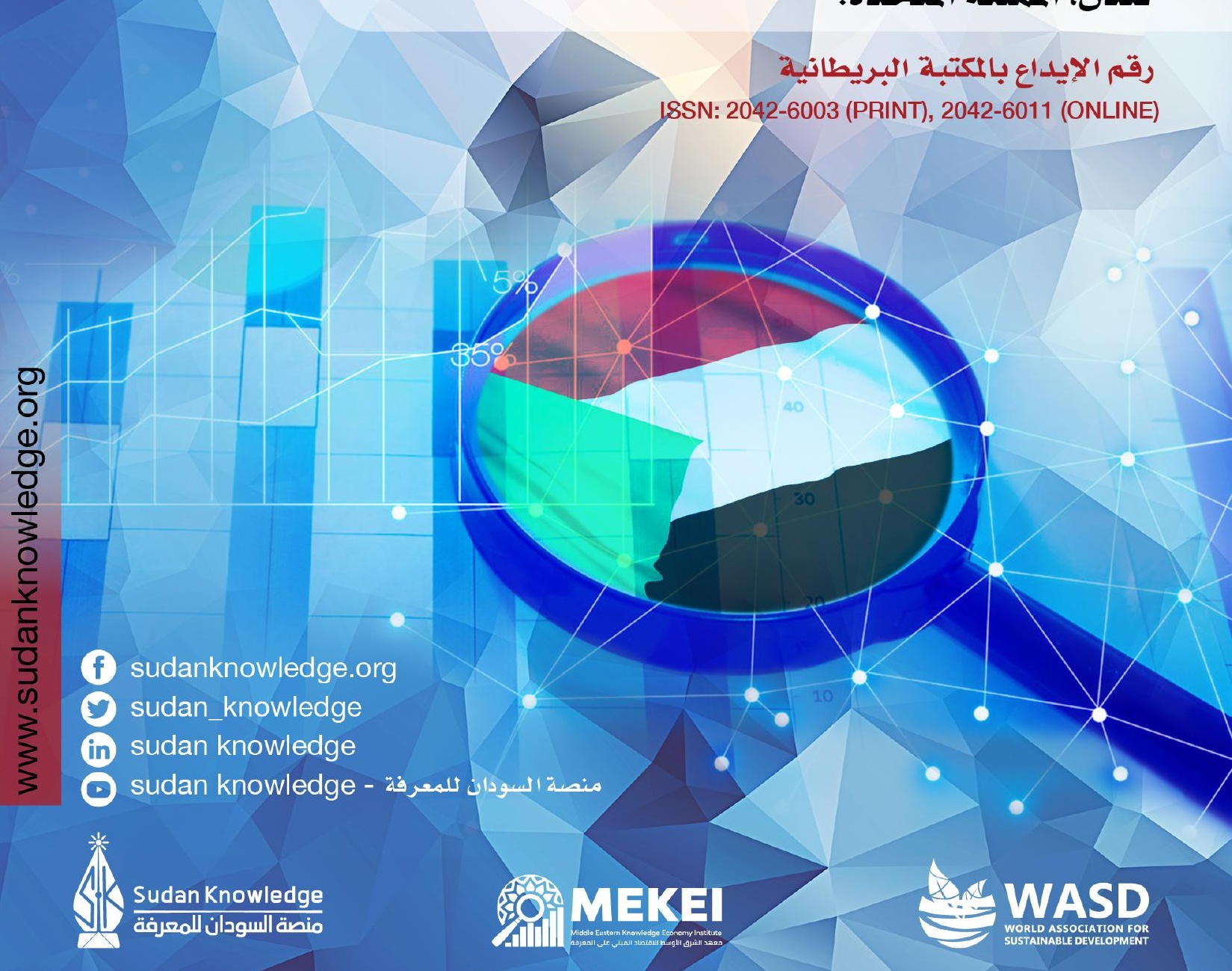




\section{Căno

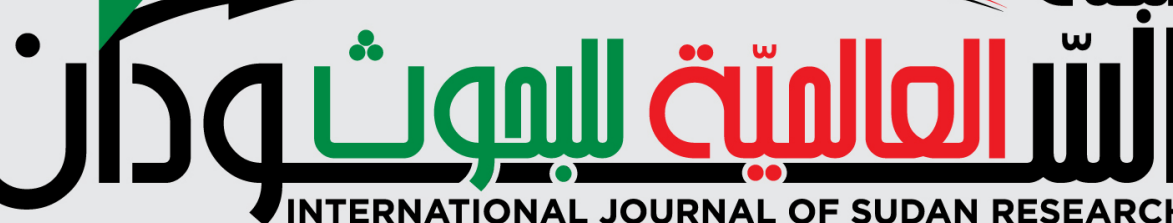

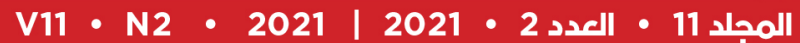

\section{RE-BUILDING THE INDUSTRIAL SECTOR} OF SUDAN

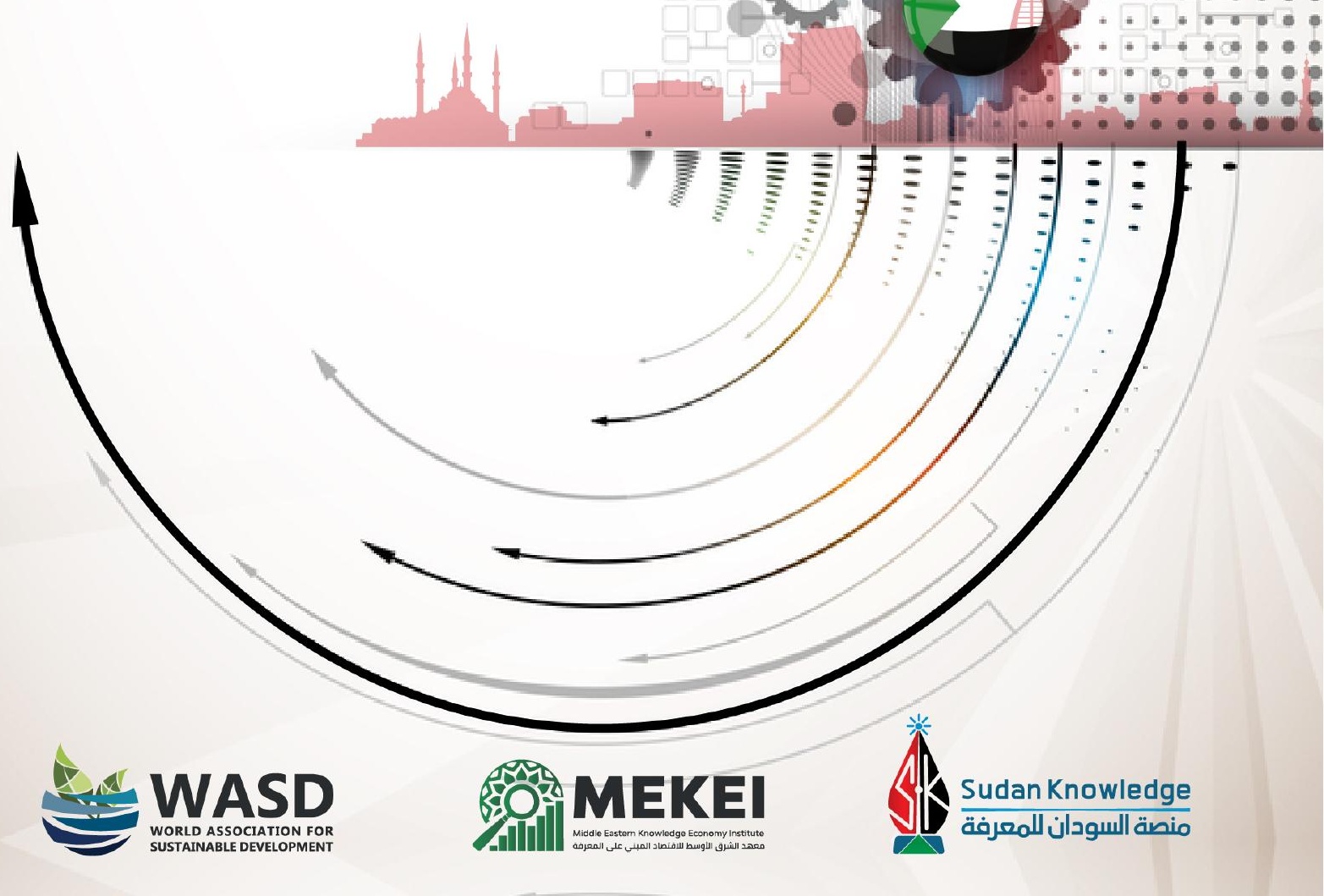




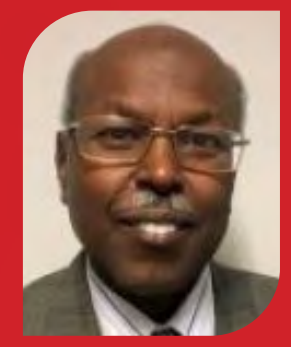

Dr. Adil Ahmed Dafa'Alla

PhD, CEng. Eurlng

Airbus, Filton, Bristol, UK

Email: adil.dafaalla@airbus.com
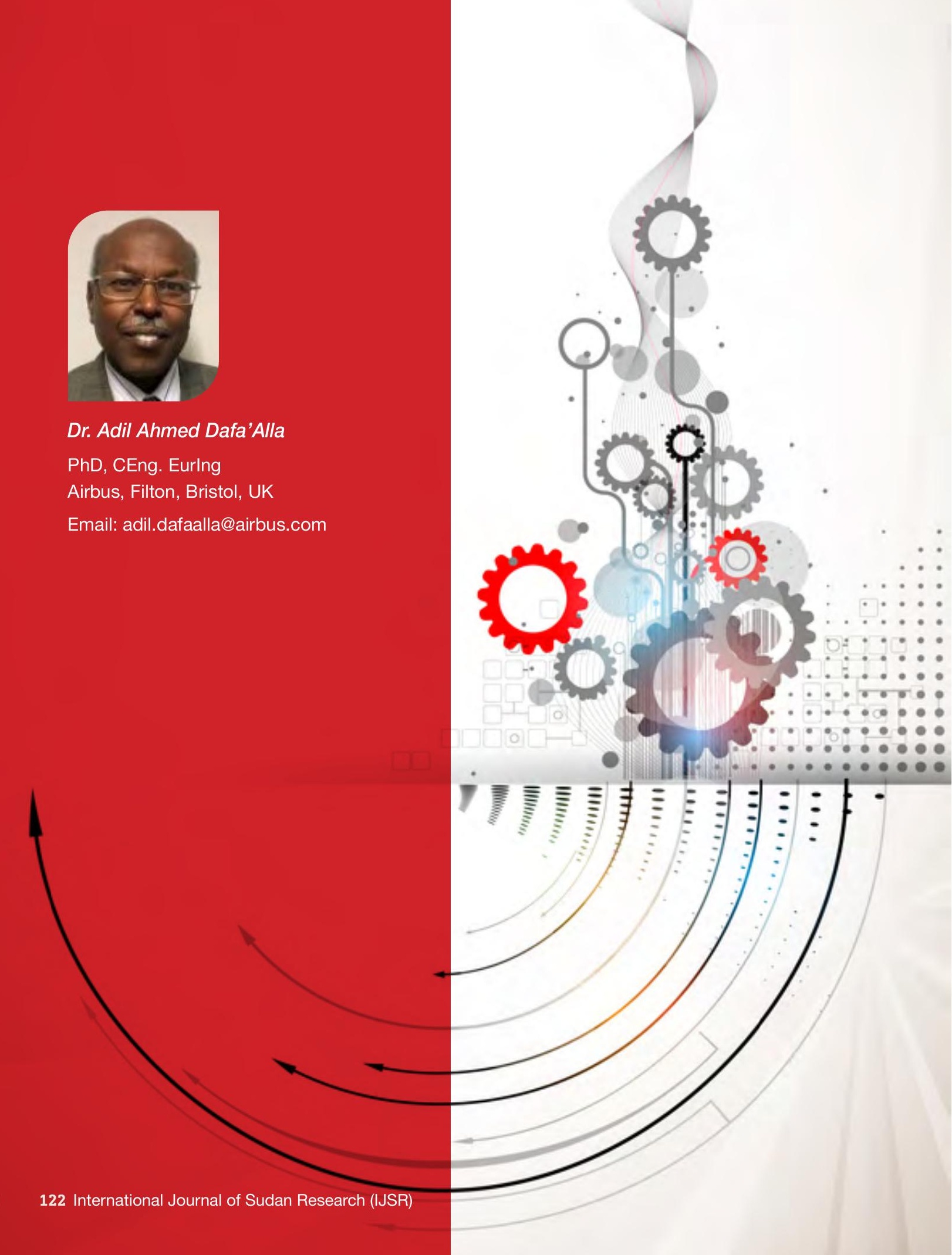


\section{Abstract}

\section{Purpose}

As a result of political instability, corruption, mismanagement and maladministration since independence, the Sudanese economy was run down and the industrial fabric of the country dismantled. This paper is a contribution towards re-building the Sudanese industrial sector.

\section{Design/Methodology/Approach}

A qualitative approach based on theoretical analysis and critical assessment was used. The raw data were collected from official sources in Sudan as well as reputable international organisations.

\section{Findings}

It was demonstrated that industry can increase the value of the raw materials many times, consequently improving economic performance. Formulating industrial strategy, policy and planning to guide the industrialisation process is key. A comprehensive path to industrialisation was offered.

\section{Originality/Value}

The systematic approach to promote industrialisation as a key tool to fight poverty and achieve high economic growth was unique and has not been addressed in this way in the literature so far.

\section{Practical Implications}

Adopting the recommendations of this paper can help Sudan to achieve sustainable economic growth and improve the standard of living for its population.

\section{Keywords}

\section{Sudan, industry, strategy, policy, plan,}

\section{economy, GDP}

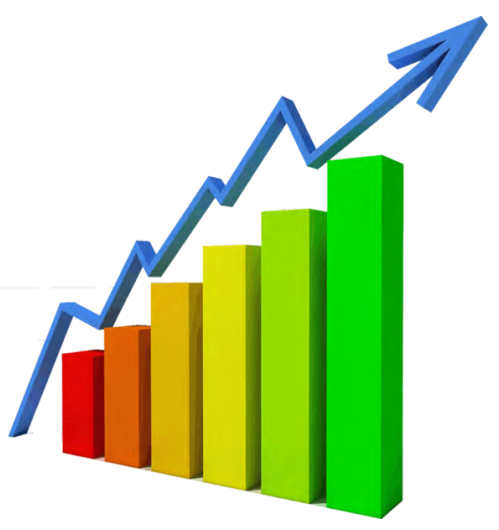




\section{Introduction}

The consensus of world economists is that the performance of the Sudanese economy is pretty dismal. Indeed, after 65 years of independence, Sudan's GDP per capita today of less than US $\$ 500$ is at the same level it was in 1980. This is not surprising noting that the industry value added to the Sudanese GDP today of less than $3 \%$ is about a quarter of its contribution in 1980 (World Bank, 2020). In addition to corruption and bad governance related to political instability, a lack of a national industrial strategy is a major reason for the economy's weak performance. Therefore, to get out of poverty and put the country's economic growth back on track, Sudan needs to formulate a national development plan with industry at its heart and main focus.

Indeed, industrial strategy is vital for providing direction and guidance for industrial and, consequently, economic development. This is because industrial development not only helps the country to accumulate capital, but also provides employment for its growing population. Furthermore, it offers a viable path for skill and technology development and transfer. It also incentivises and stimulates infrastructure development. Therefore, Sudan should formulate an industrial strategy (IS) to set the vision and guide the industrialisation process in the short-, medium- and long-term. The IS should also be supported by drafting an industrial policy (IP) to create the required investment-attractive environment and should be accompanied by an industrial plan as a tool to meet objectives of the IS in a timely,

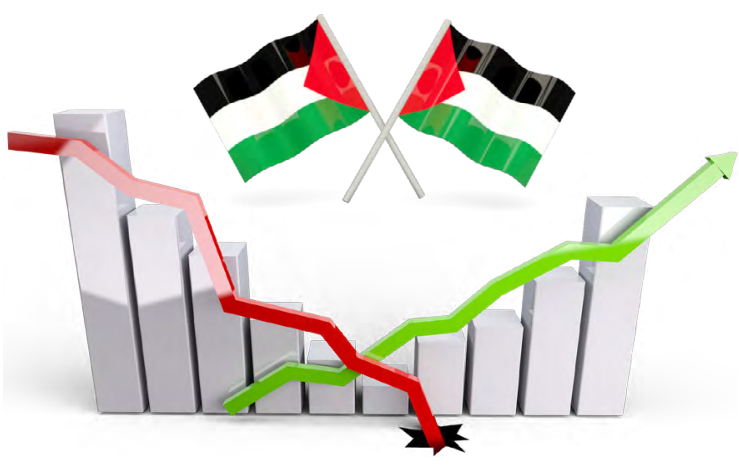

controlled and systematic manner (Dafa'Alla et al., 2017). These are the three legs on which the industrialisation process stands, as shown schematically in Figure 1.

However, the challenges are immense. To put this in context, note that agricultural lands are underused, industry value added to GDP is less than $3 \%$, live animal stocks are exported instead of processed meat and leather, and minerals, including gold, return of export to the national treasury is next to nil. These are all symptoms of lack of investment in the industrialisation of the economy. However, in addition to skill and innovation, industrial investment in Sudan also requires infrastructure and finance. Infrastructure, both physical and informational, is a pre-requisite to creating an investment-attractive environment. At the same time, it is also a hot area for investment in Sudan. There should also be clear policies to ease access to finance with reasonable cost to investors, as well as incentives through taxation policy that encourages investment. 


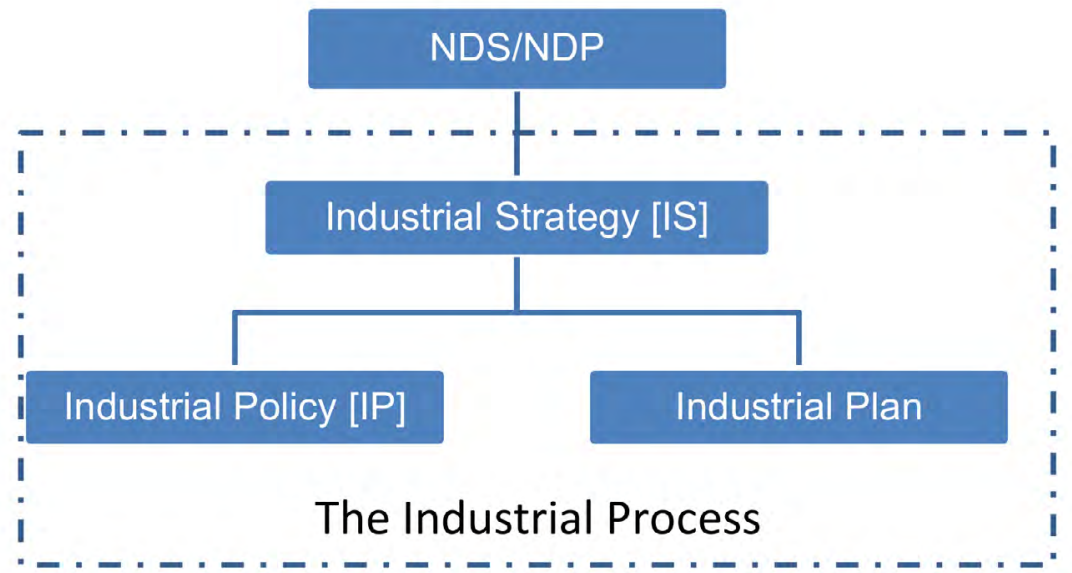

\section{Figure 1: Industrialisation Process}

Source: Constructed by author from own analysis

\section{The Case for the Industrialisation of the Sudanese Economy}

Some may argue that the Sudanese economy is largely agriculturally-based, so why should we focus on industry and give it a high priority? However, one should also note that the maximum economic benefit from agriculture can only be realised when extensive investment in agrobased and associated industries is achieved; this is because industrialisation increases the value of agricultural products many times over. This is not only applicable to the agriculture sector but indeed other natural resources, such as mining and oil. To put this in context, it is attributed to the Late President Kaunda of Zambia that he once said: "No country can balance the books if it exports raw materials and imports finished goods". Although this sounds simple, this statement underpins the importance of industry as the prime driver of economic growth and social development in any country, particularly developing countries.

In order to demonstrate this in practice, let us take the example of cotton as representative of the major agricultural products of Sudan. Ignoring by-products such as seed oil for now, cotton as an agricultural product can go through many industrial stages until it is converted into a finished product ready for human consumption. These include ginning, spinning, weaving, milling, finishing and apparel manufacturing. These stages convert the cotton to fibre, yarn, thread and fabric or cloth before being tailored 
into clothes to wear. In this process, the value of the cultivated cotton can increase by 40 fold, from US $\$ 1,633$ per metric tonne for raw cotton to US $\$ 61,807$ per metric tonne for tailored shirts, as shown in Figure 2, or even more than 40 fold for some other finished goods (USDA, 2018). This means one can never balance the books if they export cotton as raw material and import manufactured finished clothes. Or to put it in a different way, if raw cotton is processed locally up to the production of a finished product, it can yield 40 times more income from the same amount of cultivated cotton area. The real value can even be higher if one considers other finished products and the economic value of by-products. This will not only cover local need for clothes, for example, but there may also be a surplus for export that will allow the country to import other necessities for its people.

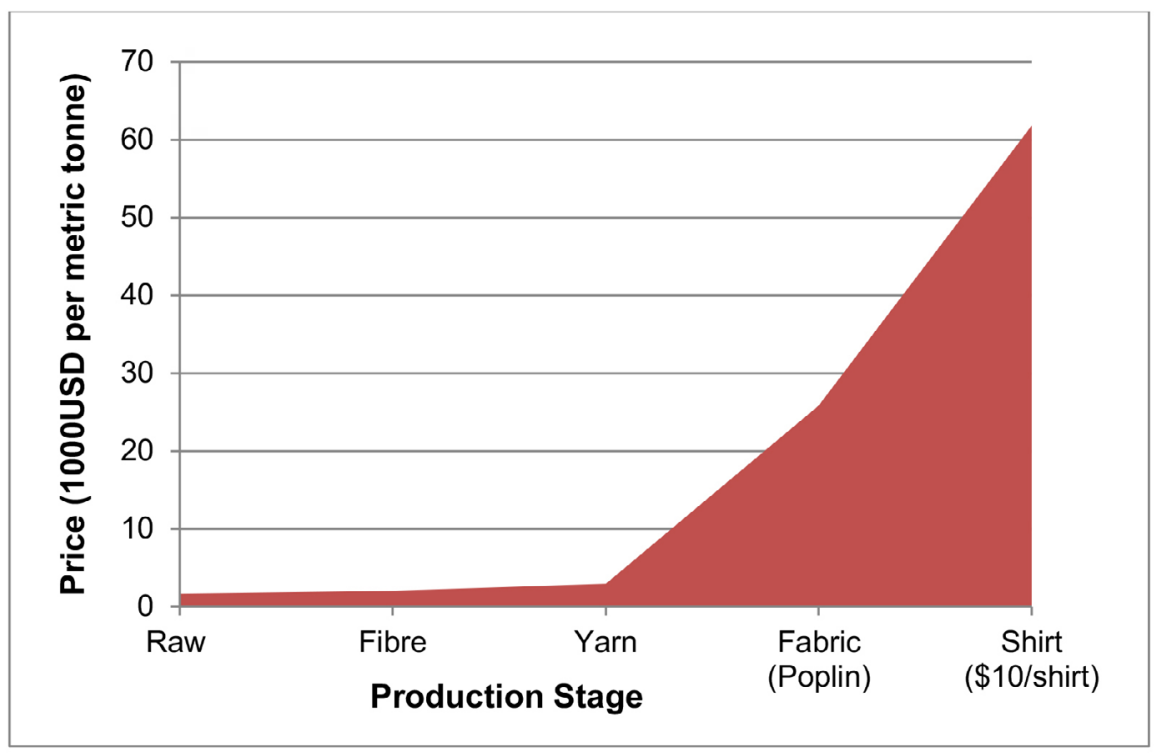

\section{Figure 2: Industrial Value Adding of Cotton}

Source: Cotton Counts, 2020a, b 


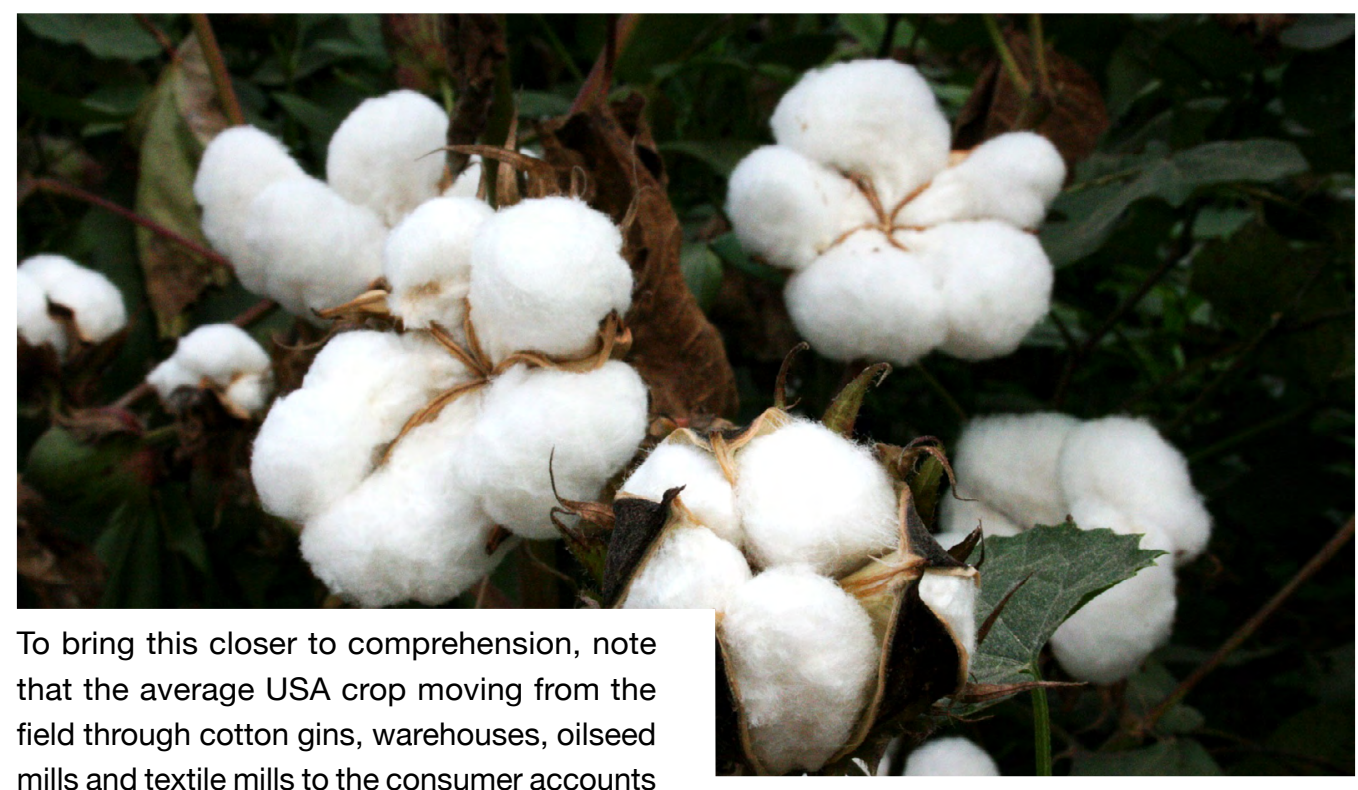

for more than US\$35 billion in products and services (Cotton Counts, 2020a); this is in addition to providing more than 440,000 jobs (Cotton Counts, 2020b). If Sudan can do the same, it can pay all its foreign debt, estimated to be about US $\$ 56.05$ billion as of 30 June 2018 in the CIA World Factbook (Index Mundi, 2020a), in less than two years. By the way, this is very realistic when one notes that the $10^{\text {th }}$ largest cotton producer in the world in 2018/2019 was Burkina Faso as per the US department of Agriculture Statistics (Statista, 2020). The whole area of Burkina Faso is less than $15 \%$ of the area of Sudan today, and the area under cotton cultivation in Burkina Faso (450,000 ha; Indian Government, 2020) is about half the Gezira Scheme in 2008 (880,000 ha; Wikipedia, 2020).

Also remember that the area under cotton cultivation in Sudan was 510,000 ha in 1970. This decreased considerably to 120,000 ha in

2018, less than a quarter of the 1970 area (Index Mundi, 2020b)! However, this also shows that expansion in the cultivated area is possible; not only to go back to the 1970 level, but surpass it to compete favourably with the 4.3 million hectares of the cotton harvested area in the US, as per 2018 figures (USDA, 2019). This can be realistically achieved through the right planning, investment and intent in place.

Therefore, a combination of expanding the cultivated area and heavy investment in agrobased industry and associated infrastructure can be a highly potent tool in Sudan's development plans portfolio. The example of cotton demonstrates the important role of industry and should be taken seriously by any developing country, not only Sudan, if they want to get out of the poverty zone and secure a decent sustainable standard of living for their respective populations. 


\section{Contribution of the Industrial Sector to the Sudanese Economy}

The industrial sector can generally be divided into manufacturing/transformational industries, such as sugar, textile and food industries, and non-manufacturing, such as construction and telecommunications. There is a consensus among economists that the performance of the Sudanese economy is a failure and the contribution of the industrial sector as a whole to it is pretty dismal, as discussed above. In order to examine this claim, take a reference point against which to measure the contribution of the industrial sector to the Sudanese economy. The figures, reports and statistics from the Ministry of Industry in Sudan are generally few and usually deficient. However, there is one good exception in this regard. This is the comprehensive industrial survey that was conducted by the Sudanese Ministry of Industry with direct support from the United Nations' agencies of UNIDO and UNDP in 2001 and reported in Dissman (2004). The survey covered over 24,000 establishments with over 10 employees, a total of over 160,000 employees. Over 130,000 of these were paid employees and the rest were non-employees, such as proprietors, family members and other unpaid workers. The survey showed that the manufacturing sector, which was the main contributor to the industrial sector at the time (50\%), contributed only $9.5 \%$ to the GDP $(1 \%$ from South Sudan) and $1.7 \%$ to the employment market, which are pretty small contributions. Additionally, the manufacturing sector share of the total export merchandise was $12.8 \%$, while its share to imports was $21 \%$; resulting in a negative trade balance of $-8.2 \%$. More recent figures from the Sudanese Ministry of Finance show that the manufacturing export share of merchandise has been gradually dropping to reach $0.04 \%$, while imports increased to $30.4 \%$ by 2014 , increasing the manufacturing trade balance deficit even further to $-30.36 \%$ (Taha, 2016). Likewise, according to the most recent figures from the World Bank (2019), the Sudanese industrial sector's contribution to the GDP dropped from $21 \%$ in 2000 to $3 \%$ in 2015 to $2 \%$ in 2017 , while the contribution of the manufacturing sector for the same period, affected by the secession of the South in 2011 and the subsequent loss of three-quarters of the productive oil fields, dropped from $9 \%$ to almost nil since 2015 (as shown in Figure 3) signalling complete collapse of the sector since then.

To put this in context, the corresponding figures for the industrial and manufacturing contributions to the GDP for sub-Saharan Africa during 2017 were $25 \%$ and $10 \%$ respectively, and for the whole world were $25 \%$ and $16 \%$ respectively. Indeed the averages for low Income countries alone were $25 \%$ and $9 \%$ (World Bank, 2019). In short, the impact of the industrial sector in the Sudanese economy today is next to non-existent. This is in line with the findings of Taha (2016) in his economic evaluation of the transformational industries in Sudan. 


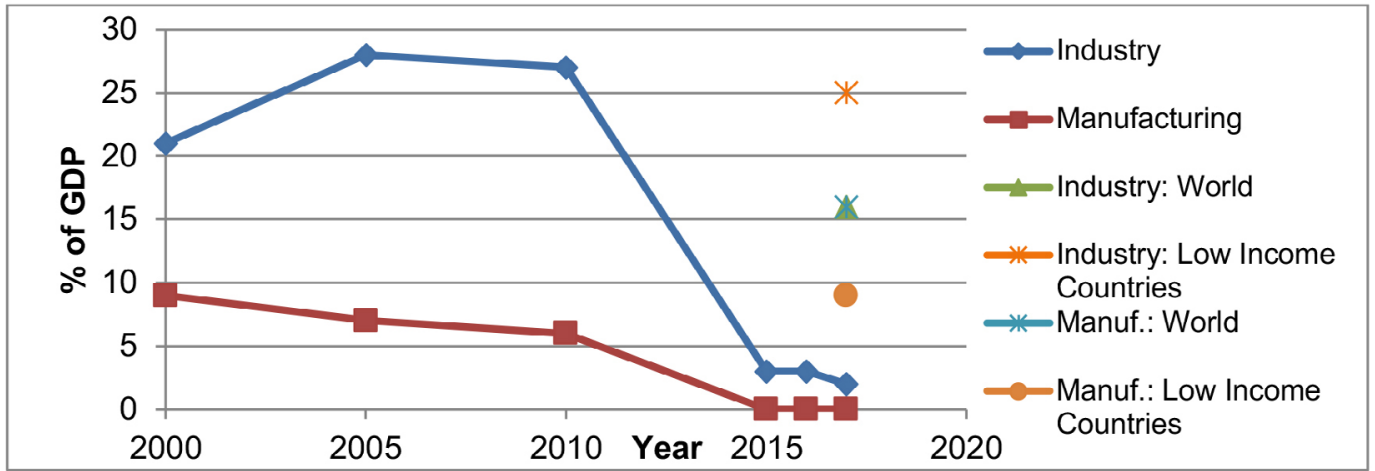

\section{Figure 3: Contribution of Industry to the Sudanese GDP}

Source: World Bank, 2016

\section{History of Industrial Strategy in Sudan}

The history of modern industry in Sudan goes back to the beginning of the $20^{\text {th }}$ century, when the first cement factory was established in Sennar to help in the efforts to build the dam there. However, the factory was shut down immediately after the dam was built. Likewise, some industries, such as cooking oil, soap and sweets, were established during the Second World War to meet local demand only to be closed down once the war was over. Atbara Portland Cement factory, which was built by a private English company in 1948, was the only serious attempt to establish modern industry in the country. The objective was to meet the high demand for quality cement for the flourishing construction industry in the UK at the time. So, it was clear that the colonial British Authority was not interested in any kind of industrial strategy for Sudan, and consequently the contribution of the industrial sector to the GDP during that period was minimal, if any.

However, the initial period following the independence of Sudan in 1956 witnessed the emergence of small and medium scale industries, such as tobacco, glass, mineral water, sweets and soap. These factories were built mainly by some foreign communities, particularly Syrian, Armenian and Greek. Although encouraged, clearly these efforts were individual private initiatives rather than a coherent strategic direction by the government. They were not underpinned by any strategic objectives. The following period was marked by political instability that impacted the industrial strategy and policies in Sudan in different ways. The strategy pendulum swung from complete nationalisation of small and medium enterprises 
(SMEs) following the May 1969 socialist coup, to market liberalisation, with only a few "strategic" industries remaining under public control, after the June 1989 Islamist coup.

The lack of clear strategic direction and the frequent change of related policies has, so far, made it very difficult for local, let alone foreign, investors to contribute to the industrialisation process in Sudan. The analysis of Dafa'Alla $(2016,2018)$ highlighted that private investors are following their own instincts and are therefore only interested in industries with high returns on investment, such as the tobacco industry, rather than encouraged through positive policies to invest in capital intensive industries, such as manufacturing, in order to help realise the national development plan. Only recently, the Ministry of Industry in Sudan has highlighted an industrial strategy on its website for the manufacturing industries sector for the period 2007-2030 (Mol, 2016), signalling that the strategy is still relevant and ongoing. However, it is not clear how much consultation and dialogue took place with stakeholders in formulating the strategy; an important step towards developing consensus around the strategy and making it resilient to political instability in the country. Although the strategy document identified the sectors or "challenges" it wanted to address at different phases of the 25-year period, it set out vague objectives for a 5-year period, rather than 25 years, and more significantly, these objectives were not "smart" enough. This is because, although the strategy, to some extent, specified "what" needs to be done, it did not say "why". Equally importantly, there was no mention of the in-depth analysis that was carried out to justify the selection of these objectives, and no specific measurable key performance indicators (KPIs) were stated. Additionally, the set of objectives is not linked to any set of "measures" regarding, for example, access to finance, taxes, skills, procurement, research and innovation, which are required to make a coherent "industrial policy". These issues are crucial to buy-in support from perspective investors and win their trust. No wonder the strategy has left little or no impact on the country's industrial map.

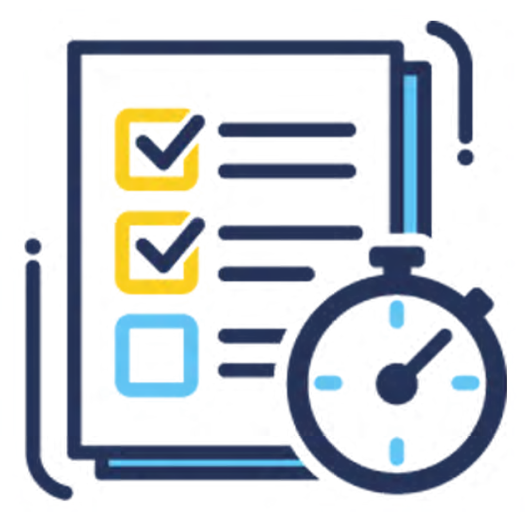

In fact, all the previous national development plans in Sudan had an industrial component to them. However, the lack of strategic vision and direction, bad governance, wrong policies, mismanagement, maladministration, favouritism and corruption were the general theme that led to their failure, particularly over the last 30 years. Figure 4 gives an historical assessment of the industrial strategies in Sudan. 


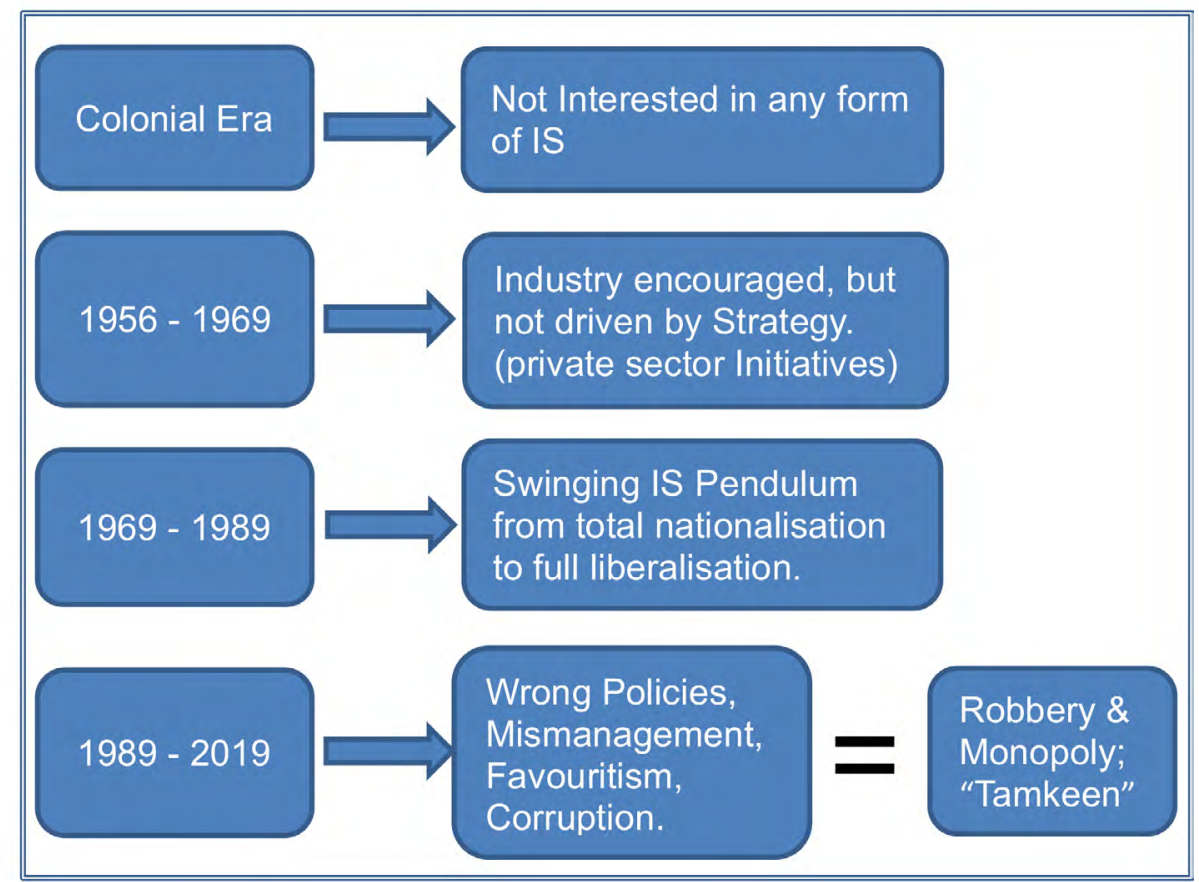

Figure 4: History of Industrial Strategy in the Sudan

Source: Constructed by author from own analysis

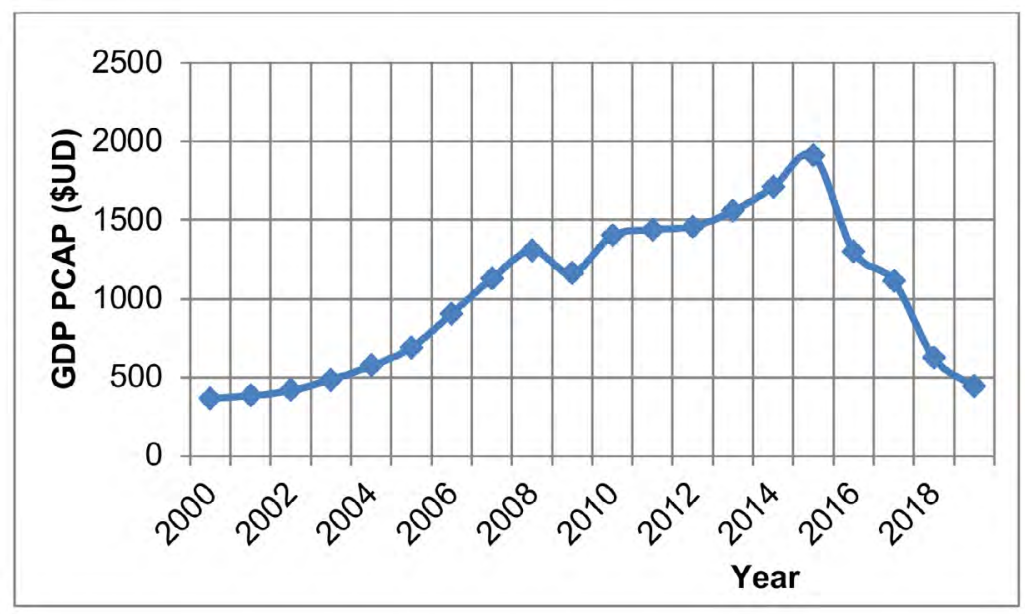

Figure 5: Sudan GDP per Capita (Current \$US)

Source: World Bank, 2020 


\section{Re-Building the Industrial Sector of Sudan}

Industrialisation is key to the future of Sudan due to its capacity to improve the trade balance, generate wealth and create jobs. It is the driver for the economy and development in any country, as noted above. Note that with the manufacturing sector being the engine of its overall resurgence, China's economic growth rate has been growing at a mind-boggling rate of around $10 \%$ for almost the last 30 years (Eurasian Times, 2020). Figure 5 shows the Sudanese GDP rising between 2000 and 2014, the same period when a reasonable contribution of the industrial sector of over $20 \%$ was observed in Figure 3. It then fell irrecoverably in 2015; the same year the industrial sector contribution to the GDP collapsed, as shown in Figure 3. Therefore, the GDP performance shown in Figure 5 closely mimics the trends of the industrial sector contribution to the economy shown in Figure 3. This demonstrates beyond doubt the organic bond between a healthy industrial sector and economic development.

Clearly, the lack of an industrial strategy was a major hurdle towards starting the industrialisation process in Sudan (see Figure 1). However, formulating the strategy cannot be done in a vacuum. As discussed above, the main reasons for the failure of previous strategies are corruption and bad governance; this underpins other factors, such as wrong policies, mismanagement and favouritism. Therefore, the starting point should be political stability and good governance with a strong anti-corruption drive. This is essential in order to establish the correct path for sustainable development, draw effective national plans and legislate for supportive policies and regulations to monitor and guide fair and strategic public and foreign investments. Note that Ethiopia with a GDP of US $\$ 80.6$ billion in 2017 (two-thirds of Sudan's GDP of US $\$ 120$ billion) (World Bank, 2019) and a population of 105 million in 2017 (increased to 115 million in 2020), 2.5 times Sudan's population of 40.53 million in 2017 (increased to 44 million in 2020) (Worldometers, 2020), is economically doing a lot better than Sudan today, largely due to political stability and good governance with a strong anti-corruption drive. However, achieving this is still only the "starting point" as it is equally important for investors to see the implementation of these policies and regulations in practice before gaining full confidence in the system. This process should start now and there is therefore no room or time for complacency.

Sudan should then urgently formulate a new fresh industrial strategy (IS) to set the vision, determine objectives and guide the industrialisation process in the short-, mediumand long-term. IET (2012) and Dafa'Alla et al. (2017) set the main ingredients for an effective industrial strategy. Note that the industrial strategy should be drafted in full and genuine consultation with all stakeholders and finalised by consensus. This will take it out of the political arena and engage all stakeholders, buying them into the process and guaranteeing their commitment throughout the implementation phase. 
The industrial strategy should also be supported by drafting an industrial policy (IP) to create the required investment-attractive environment. It should be accompanied by an industrial plan as a tool to meet the objectives of the IS in a timely, controlled and systematic manner. These will complete the three legs of the industrial process, as represented schematically in Figure 1, and signal the practical start for the country's industrialisation process. Likewise, building a competitive manufacturing sector requires heavy investment in infrastructure, skill and innovation, research and development, technology transfer and training. The education system and institutions should also play their role in providing the right quality of education and training to meet the industrial requirements, needs and demand at all levels (Dafa'Alla, 2018).
Also, it should be noted that industrial development is not cheap: it needs both capital and human resources. The government cannot do it alone: it has to be helped by genuine partnerships with private and foreign investors. Dafa'Alla and Hussein (2018) promoted a 3-way public private partnership (PPP) between the government, Sudanese Diaspora, their host countries and/or foreign investors, as depicted in Figure 6. The figure illustrates how such a partnership can work in practice to help the country to achieve sustainable economic development. It is a PPP model for formulating industrial and economic strategies, building capacity, driving sustainable development and making investment (Dafa'Alla and Hussein, 2018).

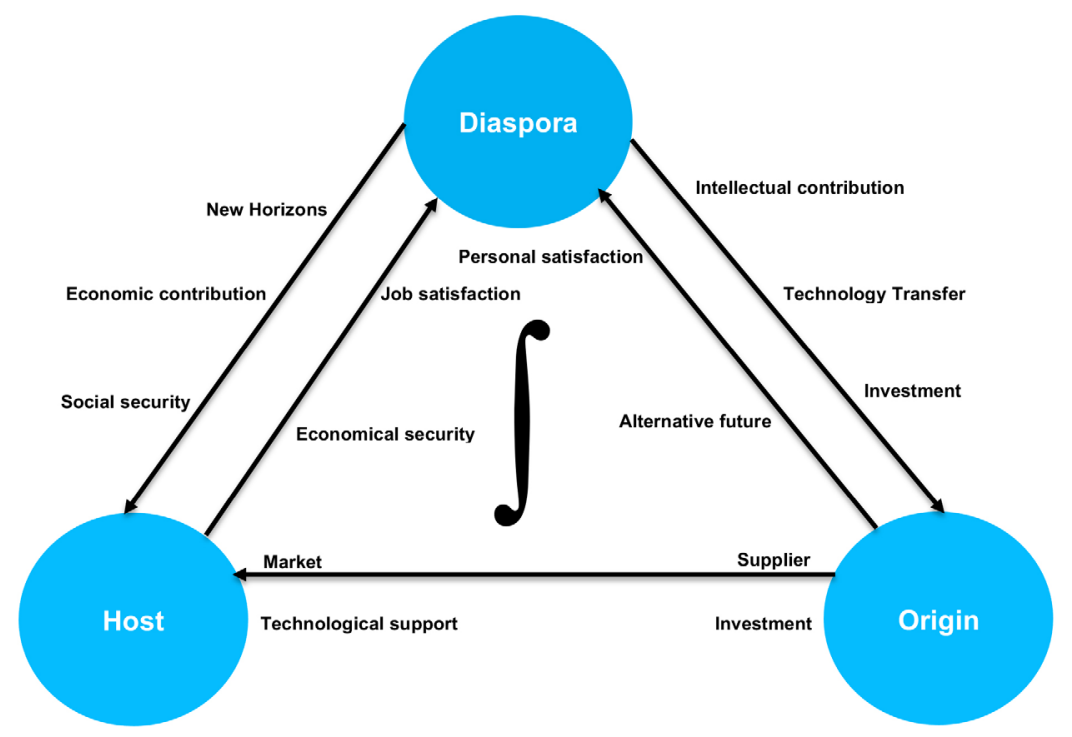

Figure 6: Three-Way PPP Model for the Diaspora as International Agents for Development

Source: Reproduced from Dafa'Alla and Hussein, 2018 
Forming and legalising such a three-way PPP can encourage and incentivise Diaspora, as well as foreign countries and sources of investment, to come to Sudan and get engaged with the country's development plans: a win-win situation. However, in addition to satisfying the above requirements, attracting private and foreign investments requires the right environment for investment and sustainable development. This comes through political and economic reforms as well as cultural change. Favourable legislation also needs to be in place in order to re-assure investors and protect their rights before expecting investors to flock to the country. These should be enshrined into the industrial policy, the aim of which is to attract investors to the industrial sector and therefore facilitate the implementation of the industrial plan.

The industrial strategy/plan, in turn, should complement and be integrated into the national development strategy/plan, as explained in Figure 7, which is reproduced from Dafa'Alla (2019). Therefore, the industrial plan should consider the country's geographical, federal and social structure. It should be formulated with the natural distribution of the raw materials and other industrial inputs and logistics in mind, as well as the required infrastructure. This could be facilitated by dividing the country into industrial zones based on the available resources and need for their development for the benefit of their local communities as well as the whole country. For example, imagine that the region of Darfur becomes the centre and "home" region for dairy products and meat processing, the Northern region for vegetables and food industries, the Nuba Mountain for mining industries, the Blue Nile region for flour mills, Kordofan for Gum Arabic processing, and the Red Sea region for developing gas, oil and fishery industry, etc. This will enhance not only the economic benefits of the industrial plan, but also the social and political objectives of the strategy. The benefits of decentralising services was also flagged by Elhiraika (2019), who promoted the uniformity of development via diversification of the economy by identifying and developing regional "economic development growth poles".

It should also be remembered that the industrial plan should consider sustainable development and the environment in its objectives. Note that sustainable development, in addition to achieving economic targets, has to reduce harm to the environment and produce regenerative impacts on natural and social systems (WCED, 1987). In other words, optimising resources to ensure continuity, preserve the environment and safeguard rights of future generations in natural resources. Therefore, the industrial plan should be formulated with the rights of future generations to natural resources in mind. This will make it beneficial, durable and consistent with international standards required to meet the UN Sustainable Development Goals (SDGs) 2030. This will help to attract international investors, who prefer to invest in countries that uphold international standards and meet their global obligations. 


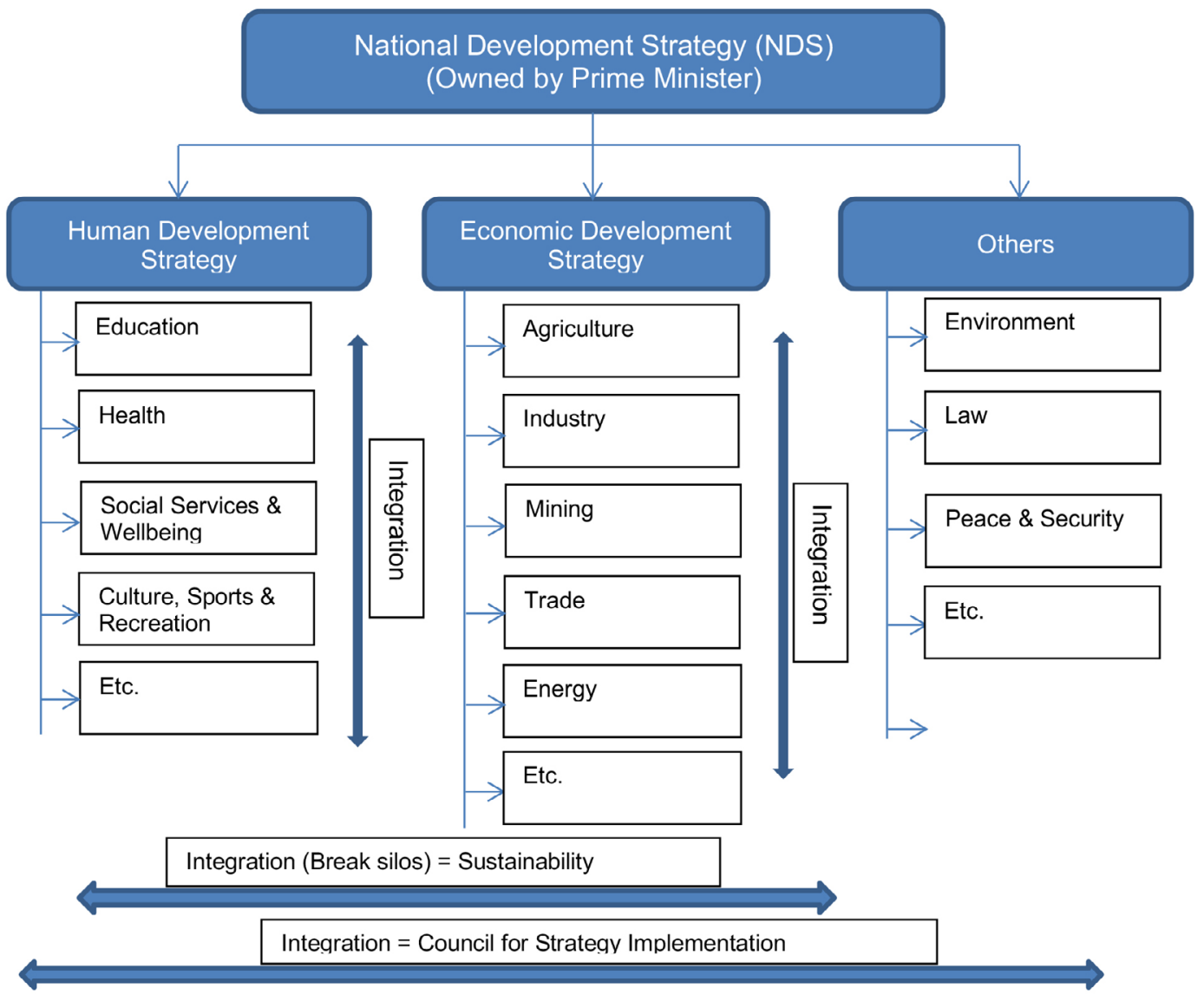

Figure 7: National development Strategy Structure

Source: Dafa'Alla (2019) 


\section{Conclusions}

- Industrialisation is key to the future of Sudan due to its capacity to improve its trade balance, generate wealth and create jobs. It is the driver for the economy and development in any country.

- The contribution of the industrial sector of $2 \%$ is noticeably small and not consistent with corresponding figures for the sub-Saharan and low income countries of the world.

- The history of industrial strategies in Sudan is not pretty. A lack of strategic vision and direction, bad governance, wrong policies, mismanagement, maladministration, favouritism and corruption were the general theme that led to their failure, particularly over the last 30 years.

- To get out of poverty and put the country's economic growth back on track, Sudan needs to formulate a national development plan with industry at its heart and main focus. Therefore, rebuilding the industrial sector must be the utmost priority for the country.

- The route to the country's industrialisation starts with political stability and the establishment of good governance with a strong anti-corruption drive. Then, formulating an industrial strategy to set the vision, determine objectives and guide the industrialisation process, supported by drafting industrial policy to create the required investment-attractive environment and accompanied by an industrial plan to facilitate the implementation phase of the strategy. This signals the real start of the country's industrialisation process.

- However, industrial development is not cheap. It needs both capital and human resources. The government cannot do it alone: it has to be helped by genuine partnerships with private and foreign investors.

- However, attracting private and foreign investments requires the right environment for investment and sustainable development. This comes through political and economic reforms as well as cultural change. Favourable legislation also needs to be in place in order to re-assure investors before expecting them to flock to the country.

- Additionally, considerations for the environment and the UN sustainable development goals should be enshrined in the industrial strategy, policy and plan.

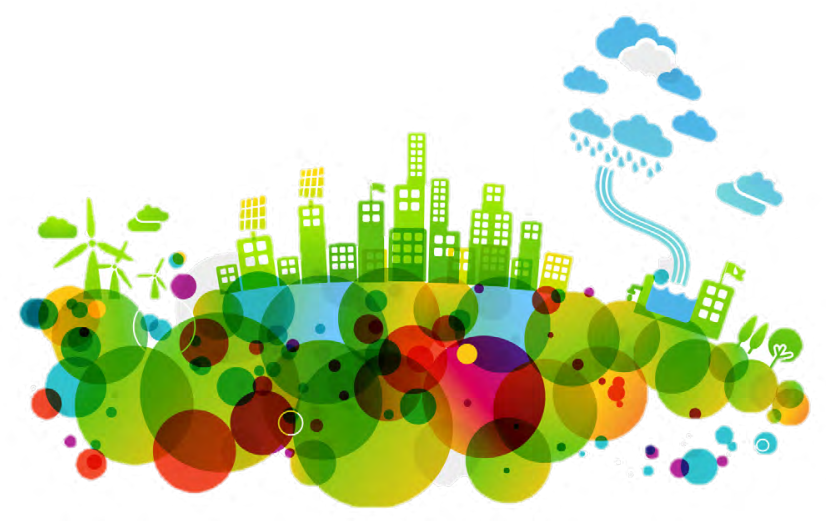




\section{References}

Cotton Counts (2020a): Cotton: From Field to Fabric, Cotton Counts Publication. Available at: https://www.cotton.org/pubs/cottoncounts/ fieldtofabric/economics.cfm?renderforprint=1, accessed 16 September 2020.

Cotton Counts (2020b): Wants you to know that Cotton Counts. Available at: http://www. cotton.org/pubs/cottoncounts/resources.cfm, accessed 16 September 2020.

Dafa'Alla, A.A. (2016): Review of the Contribution and Role of the Manufacturing Sector in the Sudanese Economy, proceedings of the $3^{\text {rd }}$ Sudanese Diaspora International Conference on The Critical Role of Diaspora in International Scientific Cooperation with the Country of Origin, London, UK, 25-26 July 2016, edited by Allam Ahmed, WASD, UK, ISBN 9781-907106-38-5, 2016.

Dafa'Alla, A.A. (2018): Critique of the Contribution of the Manufacturing Sector to the Sudanese Economy, International Journal of Sudan Research (IJSR), Vol. 8, No. 1, pp.57-72. Dafa'Alla, A.A. (2019): Industrial Development in the Sudan: Challenges and Opportunities. Presentation at the Towards Sustainable Inclusive Development in Sudan Conference, organised by the Sudan Research Group, Khartoum, Sudan, 16-18 November 2019.

Dafa'Alla, A.A. and Hussein, E.S. (2018): Towards Modelling Diaspora Role as International Agents for Development, Presented at the joint WASD $16^{\text {th }}$ International Annual Conference and $5^{\text {th }}$ International Diaspora Conference, Geneva 10-13 April 2018 on Public Private Partnerships for the implementation of the
2030 Agenda for Sustainable Development, coorganised by WASD and the UN Joint Inspection Unit. Published in Outlook 2018 as part of the World Sustainable Development Outlook Book Series edited by Allam Ahmed and published in partnership between the World Association for Sustainable Development (WASD) and Routledge/Greenleaf Publishing, ISSN 17488133., 2018.

Dafa'Alla, A.A., Hussein, E.S. and Adam, M.A.A. (2017): Towards an Effective Industrialisation process in The Sudan, International Journal of Sudan Research (IJSR), Vol. 7, No. 2, pp.85-102. Dissman, B. (2004): Report on the Comprehensive Industrial Survey, 2001, Central Bureau of Statistics, Federal Ministry of Industry, The Republic of Sudan, with Support from United Nations Industrial Development Organisation (UNIDO) and United Nations Development Programme (UNDP), November 2004.

Elhiraika, A.B. (2019): Creating Multiple Growth Poles and Empowering the States for Inclusive and Transformative Development. Paper presented at the Towards Sustainable Inclusive Development in Sudan Conference, organised by the Sudan Research Group (SRG), Khartoum, Sudan, 16-18 November 2019.

Eurasian Times (2020): IMF Admits China has Overtaken the US as the World's Largest Economy; but why is the Media Silent? Published online in The Eurasian Times by the Eurasian Times Desk on 18/10/2020. Available at https://eurasiantimes. com/imf-admits-china-has-long-overtaken-theus-as-the-worlds-largest-economy-but-why-isthe-media-silent/, accessed on 21 October 2020. 
IET (2012): Engineering an industrial strategy, A position statement provided by the Engineering and Technology, Stevenage, UK. Available at: https://www.theiet.org/media/1648/industrialstrategy.pdf, accessed 1 October 2020.

Index Mundi (2020a): Country Facts: Sudan - Debt - External. Available at: https://www. indexmundi.com/g/g.aspx?c=su\&v=94, accessed 16 September 2020.

Index Mundi (2020b): Sudan cotton area harvested by year. Available at: https://www. indexmundi.com/agriculture/?country=sd\& commodity $=$ cotton\&graph=area-harvested, accessed 16 September 2020.

Indian Government (2020): Burkina Faso Cotton Technical Assistance Programme for Africa. Published by the Government of India. Available at: http://www.cottontapafrica.org/ burkina-faso.html. Accessed 02 May 2021. Ministry of Industry (Mol) (2016): Strategy of Manufacturing Industries Sector for the Period 2007-2030, Ministry of Industry (Mol), Sudan Government website: Available at: http:// industry.gov.sd/ennn/main/prog.htm, accessed 19 April 2016.

Statista (2020): Leading cotton producing countries worldwide in 2019/2020, https:// www.statista.com/statistics/263055/cottonproduction-worldwide-by-top-countries/, accessed 16 September 2020.

Taha, A.T.S. (2016): Economic Aspects of the Transformational Industries (TI): An Evaluation Study of Sudanese (TI) during (2004/2005 up to 2013/2014), Applied Economics and Finance, Vol. 3, No. 3, ISSN 2332-7294, E-ISSN2332-7308, Published by RedFame
Publishing. Available at: http://aef.redfame.com. US Department of Agriculture (USDA) (2018): Cotton Price Statistics 2017-2018, Annual Report, Vol. 99 No. 13, August 2018.

US Department of Agriculture (USDA) (2019): Cotton Outlook, USDA's 95 $5^{\text {th }}$ Annual Agricultural Outlook Forum, Arlington, Virginia, USA.

Wikipedia (2020): Gezira Scheme. Available at: https://en.wikipedia.org/wiki/Gezira_Scheme, accessed 16 September 2020.

World Bank (2016): World Development Indicators: API_NV.IND.TOTL.ZS_DS2_en_ excel_v2. Available at: http://data.worldbank. org/indicator/NV.IND.TOTL.ZS, accessed 30 December 2020.

World Bank (2019): World Development Indicators: Structure of Output. Available at: http://wdi.worldbank.org/table/4.2, accessed 17 June 2019.

World Bank (2020): World Development Indicators: API_NY.GDP.MKTP.CD_DS2_en_ excel_v2_1345121. Available at: https://data. worldbank.org/indicator/NY.GDP.MKTP.CD, accessed 29 September 2020.

World Commission on Environment and Development (WCED) (1987): Centre for a world in balance - Our Common Future. Report of the World Commission on Environment and Development, Geneva, 1987. Available at: https://sustainabledevelopment.un.org/ content/documents/5987our-common-future. pdf. Accessed 02 May 2021.

Worldometers (2020): Population by Country. Available at: https://www.worldometers.info/ world-population/population-by-country/, accessed on 23 September 2020. 


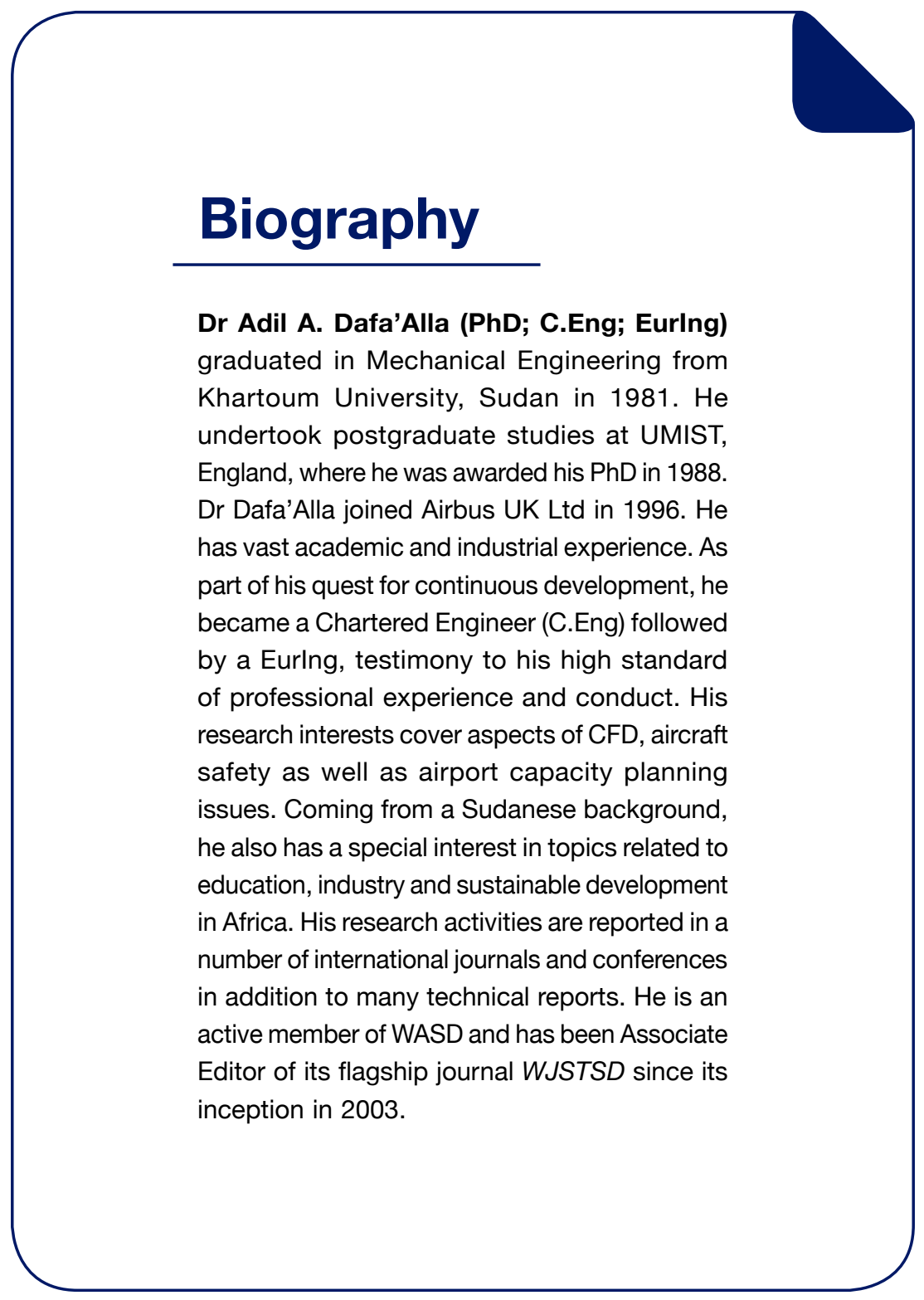

